\title{
Behavioral Perspective of Strategic Human Resource Management: Theoretical Causality Model
}

\author{
Audia Junita \\ Department of Management \\ Sekolah Tinggi Ilmu Ekonomi Harapan \\ Medan, Indonesia \\ stie.harapan.medan@gmail.com
}

\begin{abstract}
- this paper is a holistic study of how value is created in organization, from behavioral perspective of strategic human resource management. Alignment between organizational strategies, human resource system and employee role behavior contribute significantly to organizational performance. However, theoretical and empirical studies exist previously, analyzed causal relationships between variables in behavioral perspective of strategic human resource management in linear manner. The main objective of this paper is to synthesize theoretical and empirical studies related to causal relationships between variables in behavioral perspective of strategic human resource management. The results of literature review indicate that there are interdependence relationship between variables in behavioral perspective of strategic human resource management. That interdependence relationships are illustrated in integrative theoretical model in behavioral perspective of strategic human resource management, which become a major contribution of this paper. Suggested theoretical model can be used to improve understanding of how organizational performance is achieved by optimizing strengthens of organization's internal resources. Further empirical studies are needed to understand interdependence relationships between variables by relying on empirical data.
\end{abstract}

Keywords : Theoritical Model, Behavioral Perspective of Strategic Human Resource Management

\section{INTRODUCTION}

Maximizing value for the owners is the main orientation of business organization. Efforts to value creation of organization's output are determined by the value of resources as inputs and systems used by organizations to convert input into output values [47].

Resource-based view asserts that capability and organizational internal resources are effective used to exploit environmental opportunities and neutralize threats [5]. Characteristics of organizational resources which are valuable, rare, difficult to replicate and well-organized by organization will be determine competitive advantage of organizations [5], [43], [47], [63].

Human resource is an important organization's asset [6]. Nothing can be achieved by organization, without human. Humans are no longer positioned as a resource but rather as a capital for organizational investment purposes in the long term.
Besides human, management mechanism which is used to achieve strategic value to organization is an important asset [10]. Management mechanism determine organization's ability to compete [5], [6], [11], [28], [43], [63]. Specifically, policies and practices of strategic human resource management are the best way to differentiate one organization with other organizations, and also the most significant tool to achieve competitive advantage of organizations [28].

Human resources management strategic activities include designing and implementing policies and practices of human resource management that facilitate human capital contribute to organizational goals achievement [2], [4], [11], [26], [27], [33], [63], [64]. It also means that all activities in human resource management have strategic meaning in implementing organizational strategy, ultimately lead to organizational competitive advantage [42]. It means that strategic human resource management associated with business strategic initiatives [1], [4], [11], [28], [29], [63].

Strategic human resources management contributes to higher organization's value creation through human resource system [11], [19], [44], [45]. It is a mechanism used to capitalize the human assets into organization's value wants to achieve. Human resource system is "invisible assets" that able to create value as a part of the organization's operational systems. Operating systems as an "invisible assets" have a long-term competitive ability than "visible asset" [32].

Human resources system are termed as complementary resource [5], infrastructure requirement [63] and structural capital [43]. System perspective of human resource management policies and practices based on the idea that the practices of human resource management serve as a "bundles" [45], "groups" or "clusters" [30] that are complementary to one each other, as a human resource system.

The concept of alignment is important in human resource system. Alignment between various dimensions of context and organizational design [21], [33]. Alignment in human resource system include internal and external alignment. Internal alignment as complementarity between various practices in human resources system [4] and external alignment puts organization's strategy as a contingency factor affecting human resource system [19], [33], [64]. Human resource system which have internal and external alignment are believed capable to give greater contribution to organizational 
performance achievement, compared with human resource system that do not [4], [10], [19], [31], [42], [64], [63], [72], [76].

Mechanism of how human resource system contributes to organizational performance achievement become the focus of strategic human resource management experts. Individual becomes an important mediator variable in the relationship between human resource systems and organizational performance.

The dynamic then arises because the relationship between management and workers do not always work in harmony. It happens because each party has different interests and goals. Organizational members tend to give attribution to human resource management practices vary and then have an impact on their work attitudes and behavior, and then organizational performance [38], [52], [58], [77]. Mechanism how human resource decisions influence the creation value in organization, is complex and not easily understood [10]. Behavior be an important mediator in the relationship between human resource system and performance organization [9], [12].

Individual work behavior related to its role in organization [38]. In organization, each individual role is required to meet expectations of various parties. Because of that, various form of behaviors displayed by individual in organization. Role behavior variations emerged as a result of individual's perception of various organizational policies, including human resource system. In this case, human resources system is the main tool used by organizations to send role information, reinforce desired behavior and evaluate role performance, to meet organizational stakeholder's role expectations [39].

It is related to the main assumption of behavioral perspective in strategic human resource management that suggests typology of human resource system and role behavior, in line with organizational strategy as contingency factors that affect all processes taking place in organization [64]. Human resource system and role behavior are a mechanism used to implement organization's strategy. Therefore, different strategy needs different characteristics of human resource system as well as role behavior required to implement organizational strategy, towards achievement of organizational goals effectively.

The theoretical problem then arise related to complexity of causal relationship between organizational strategy, human resources system, role behavior and organizational performance, because of studies involving these variables which had been done, only in linear causal relationship analysis [15], [38], [58] although various theoretical and empirical recommendations is given by the experts, propose to test non-linierity relationship between variables in behavioral perspective of strategic human resource management [10], [14], [26], [25], [59], [68], [72], [73], [74], [75].

That research background become the basic thinking of this paper. The main goal of this paper is to analyze the dynamic of linkage variables in behavioral perspective of strategic human resource management as a system, which include subsystems such as organizational strategy, human resource system, role behavior and organizational performance.

\section{RESEARCH METHODOLOGY}

This paper is based on a literature review, regarding the relationship between variables in behavioral perspective of strategic human resource management. A literature review conducted on books, scientific journals, scientific proceedings that are considered able to scientifically answer this paper's purposes. The results of the literature review are analyzed descriptively.

\section{FINDINGS AND DISCUSSIONS}

Focus study of strategic human resource management field oriented to increase organization performance. Concept of strategic human resource management as an interrelation between three concepts namely strategy, organization and human resource management [22]. The concept of strategy implies the outcome of organizational effectiveness such as organization performance, individual performance or success in achieving strategic objectives implementation. Therefore, human resource management in strategic perspective focused on how to adjust the activities of human resource management with desired outcomes to be achieved.

Mechanism of how human resource management practices contribute to the achievement of organizational performance become the focus of theoretical and practical experts in strategic human resource management. Various studies have proved that attitudes and behavior of individuals is an important mediation mechanism through which human resource system contribute significantly to organizational performance [9], [10], [11], [12], [48], [52], [56], [58], [69], [73], [74].

Behavioral perspective in strategic human resource management explains archetype of relationship between organizational strategy, human resource management practices, role behavior and organizational performance Basic assumption of behavioral perspective in strategic human resource management assumes that difference strategy requires difference human resource management practices and employee's role behavior in organization [64]. According to Schuler \& Jackson's archetype, human resource management practices and role behavior are a mechanism used to implement organizational strategy [64]. This is due to organization's strategy includes various decisions that were able to define the organization's relationship with its environment (dimensions of content) and be able to provide direction for operational and administrative activities that run the organization (process dimension) [66].

Organizational strategy is a deliberate efforts by organization to select a series of different activities with that undertaken by competitors [62]. Competitive strategy is a formula determined by organization to achieve organizational goals [60]. Organization's strategy includes various decisions that be able to define organization's relationship with its environment (dimensions of content) and provide direction for 
operational and administrative activities which is run by organization (process dimension) [66].

Porter's generic strategies are used as an archetype in behavioral perspective of strategic human resource management [60], [61]. Generic competitive strategies proposed by Porter are type of organizational strategy based on competitive scope, include cost-leadership, differentiation and focus strategy [60], [61]. Cost-leadership strategy emphasis on competitive advantages in efficiency and cost minimization compared to its competitors in the same industry. Differentiation strategy emphasis on producing and marketing product or service that is unique based on the preferences of buyer. This strategy can be based on product differentiation, service systems and marketing techniques that are set to sell the product. Reputation is important for consumer products. Focus strategy, oriented on customer segments, product line, region specific marketing exclusively. Strategies focus leaning on the premise that organization will be better to serve narrower target market. Strategy focus includes cost-leadership and differentiation focus.

Associated with Porter's typologies of organizational strategies, organization's strategies are categorized as "lowroad" strategy that focus on cost-leadership and "high-road" strategy that focus on quality, variety or service [54]. More specifically classify variables of differentiation competitive strategy are classified as marketing and innovation differentiation [41], [49], [50]. Dimensions differentiation innovation is characterized by organizations that are adaptive, excellence in new products and technologies, high innovations, emphasis on research and development activities, so that organization can determine relatively high price. While the dimensions of the marketing differentiation, is applied by many organizations that offer attractive packages, great location, reliability of products and good services. This organization has advantage as a marketer, spend a lot of money for advertising, sales, promotion and distribution, but they rarely put out new products.

From that explanation, it is shown that there are different strategies typologies in behavioral perspective of strategic human resource management. Nevertheless, various typologies of organizational strategies in behavioral perspective of strategic human resource management are still in line with Porter's generic competitive strategies, as a basic strategies typology. Characteristic Porter's innovation strategy synonymous with innovation differentiation strategy [41], [49], [50]. Porter's quality-enhancement strategy synonymous with marketing differentiation strategy while focus strategy is not a part of behavioral perspective in strategic human resource management typologies [41], [49], [50]. The measurement of focus strategy may lead to misinterpretation, because its strategy can be oriented on "cost-leadership" and "differentiation" strategy in a limited segment [34].

Empirically, causal relationship between organizational strategy and organizational performance proves that organizational strategy content has significant effect directly on organizational performance [3], [8], [20], [40], [50], [51]. Porter's generic competitive strategies empirical studies and their effects on organizational performance provide varied results related to the implementation of strategies or combination of strategies towards the achievement of organizational performance. Although according to Porter, organization which execute one strategy as the main target, would contribute to better organizational performance, but in practice, sometimes organization success to implement combination of generic strategies Porter [60].

However, empirical studies within the scope of organizational strategy was criticized by Ginzberg \& Venkantraman by stating contingency perspective framework in strategy research [25]. According to Ginsberg \& Venkantraman, strategy research include activities related to organization's strategy formulation and implementation [25]. However, empirical studies related to organization's strategy formulation, is still very limited to do. The influence of organizational variables like human resource system and organization's performance to strategy's formulation are also important to analyze. Ginsberg and Venkantraman framework showed that the achievement of organization's performance and organizational variables like human resource system plays an important role, as a corrective feedback for organization's strategy formulation at a later stage. The choice of strategy is conditioned by the level of organizational performance [23].

In addition, Ginsberg \& Venkantraman consider that the existence of intervening variables (organizational variables) also become an important factors in the relationship between strategy and organizational performance [25]. Human resource system is intervening variable used by organizations to implement organizational strategy. Human resources system characteristic which are align with organization's strategy has significant effect on organizational performance [16], [17], [18], [19], [27], [29], [76]. Human resource system can also be a feedback for determining the next phase of organizational strategy. Through the framework alignment in strategic human resource management strengthens the argument that actual human resources system of organization and the achievement of organizational performance be a formal feedback to the determination of the organization's strategy [72].

The dynamic of individual differences in perception, attitude and behavior towards human resource system varied contribute to the achievement of organizational performance. Effective management practices require an organization's understanding of individual differences. Ability in predicting employee's behavior and performance is the goal of management in every organization [24].

Human resource system is a mechanism used by organizations to transmit role expectation to employees to keep pace with stakeholder's expectations. Various studies have proved that attitude and behavior of individual is an important mediation mechanism through which human resource system contribute significantly to organizational performance [9], [10], [11], [12], [48], [52], [58], [56], [69], [73], [74].

Katz (1964) categorized role behavior into two categories: in-role behavior and extra-role behavior [71]. Inrole behavior meets or exceeds performance standars including quantitative and qualitative standards which are 
stated in job description of a role, while extra-role behavior is an innovative and spontaneous behavior, a form of performance outside of role requirements but useful for organizational achievement. Organizational citizenship behavior (OCB) [7], [67]. Work engagement is a concept which is used to describe employee behavior in assigned task. It is manifested behaviorally as Passionate Task Performance (PTP) and Organizational Citizenship Behavior (OCB) [55]. OCB result in more effective service delivery to organizational standards [13]. Even service-oriented OCB, a part of extra-role behavior significantly influences customer satisfaction and loyalty [57].

Causal relationship related to organizational strategy and employee role behavior are also explained in behavioral perspective in strategic human resource management. Based on that perspective, different strategy not only needs different specific role behavior, but also certain human resource system. Innovation strategy requires a wide range of human resource system oriented to task commitment as well as creative role behavior. Quality-enhancement strategy requires human resource system which have high sense of commitment to organization and conduct of process-oriented role behavior. While cost-leadership strategy requires control-oriented human resource management practices and result-oriented role behavior.

Alignment between organizational strategy, human resource system and specific role behavior are also explained in alignment framework of strategic human resource management [72]. Human resource system and role behavior which are align with organizational strategy will be contribute to high of organizational performance [72]. Then, achievement level of organization performance will be a feedback for the next strategy and intended-human resource system.

Causal relationship between organizational performance and role behavior, theoretically, who combined HR Scorecard and Balanced Scorecard as a comprehensive framework of performance measurement systems [9], [12], [36], [37]. That framework described that organizational financial performance could be a feedback to employee's strategic behavior. Empirical studies also proved that organizational performance can be influence employee's attitude, as an impact of organizational performance achievement [35], [65]. Attitude is a predisposition of behavior, because of that, attitude can be used to predict behavior. Therefore, it can be concluded, that organizational performance can be placed as a dependent and independent variable [46].

Several empirical studies related to behavioral perspective in strategic human resource management, explained more specific about causal relationship between characteristic of organizational strategy, human resource systems and role behavior. Research results show that organization with a costleadership strategy tend to be cost control-oriented and activities of human resource system emphasis on low mastery of skills requirements, providing limited training, relatively low wages, the lack of procedures for filling complaints. In human resource system like that, commitment of the employee will be low [1], [2]. Contrast in organization implementing differentiation strategy, organization tend to implement commitment-oriented human resources system where organization should be able to rapidly respond the changing of environment and demands of the market, so it needs skilled workers and getting various training extensively to perform various different tasks. Differentiation strategy tend to be able to create an organizational commitment (psychological bonds) and work behavior expected as well as a high performance organization.

In line with that research, empirical study results, proved that commitment-oriented human resource system can leverage positive behavior of employees, whether in-role or extra-role behavior, because of their relational psychological contract between organization and employee, which is raised from that system [70]. Individual attribution on human resource system concerned with quality-enhancement strategy and employee's welfare, significantly and positively impact on employee's high-commitment attitude or behavior while the individual attribution of human resource system which concern with cost-leadership strategy as well as activities of exploiting employees, has significantly and negatively effect towards attitude or behavior of employees.

Table 1 concluded that human resources systems are closely linked to specific organizational strategies. Organizations with differentiation strategy and highcommitment human resource system are able to leverage employee's high-commitment attitude and behavior which will further contribute to organizational performance. Organizational commitment rests on a strong belief against organizational values that requires psychological identification of organizational purposes, values and involvement [53]. Similarly, organizations with cost-leadership strategy and control-oriented human resource system, relatively having employees with employee's low-commitment attitude and behavior.

Table 1. Typologies of Organizational Strategy, Human Resource System and Role Behavior

\begin{tabular}{cccc}
\hline \hline $\begin{array}{c}\text { Organizational } \\
\text { Strategy }\end{array}$ & $\begin{array}{c}\text { Human } \\
\text { Resource } \\
\text { System }\end{array}$ & $\begin{array}{c}\text { Role } \\
\text { Attitude/Behavior }\end{array}$ & $\begin{array}{c}\text { Employee } \\
\text { Orientation }\end{array}$ \\
\hline \hline $\begin{array}{c}\text { Cost- } \\
\text { Leadership }\end{array}$ & $\begin{array}{c}\text { Control- } \\
\text { Oriented HR } \\
\text { System }\end{array}$ & $\begin{array}{c}\text { Low- } \\
\text { Commitment } \\
\text { Attitude/Behavior }\end{array}$ & $\begin{array}{c}\text { Employee } \\
\text { Exploitation }\end{array}$ \\
\hline Differentiation & $\begin{array}{c}\text { Commitment- } \\
\text { Oriented HR } \\
\text { System }\end{array}$ & $\begin{array}{c}\text { High- } \\
\text { Commitment } \\
\text { Attitude/Behavior }\end{array}$ & $\begin{array}{c}\text { Employee } \\
\text { Welfare }\end{array}$ \\
\hline \hline
\end{tabular}

a. Source : [1], [2], [52], [68]

Furthermore, employee's attitude and behavior will contribute positively to customer satisfaction [52]. Highperformance human resource system has significantly effect on organizational performance [68]. That system is mediated with service oriented OCB and moderated by service-oriented quality-enhancement strategy.

Advice regarding cusality relationship between OCB and organizational performance is provided by Podsakoff \& MacKenzie [59]. OCB can significantly contribute to 
organizational effectiveness and vice versa, an organization that performs well, will have employees with high job satisfaction which would then stimulate OCB towards productive efficiency.

The same thing to test a recursive relationship between productivity as a form of organizational performance and OCB [68]. A revised model of strategic human resource management is suggested, related to causality relationship between strategy, human resources system, human capital, organizational behavior and performance [26]. One relationship that needs to be examined further is a recursive relationship between employee behavior and organizational performance.

From empirical studies which is explained before, it can be concluded that selection of a particular organizational strategy requires human resource system which is appropriate. Alignment between strategies and systems are able to leverage organizational positive work behavior toward the achievement of organizational performance. In this case, role behavior is a mediating variable that reveal the black box between human resource system and organizational performance. Organizational performance, from the standpoint of strategic human resource management,is influenced by a number of elements. In behavioral perspective of strategic human resource management, organizational performance is influenced by organizational strategy, human resource system and role behavior variables. Organizational performance can be placed as a dependent and independent variable. Achievement of organizational performance, as well as actual employee role behavior and human resurce system, will be a feedback for the next formulation of organizational strategy, intended human resource system and characteristic employee role behavior which is needed by organization.

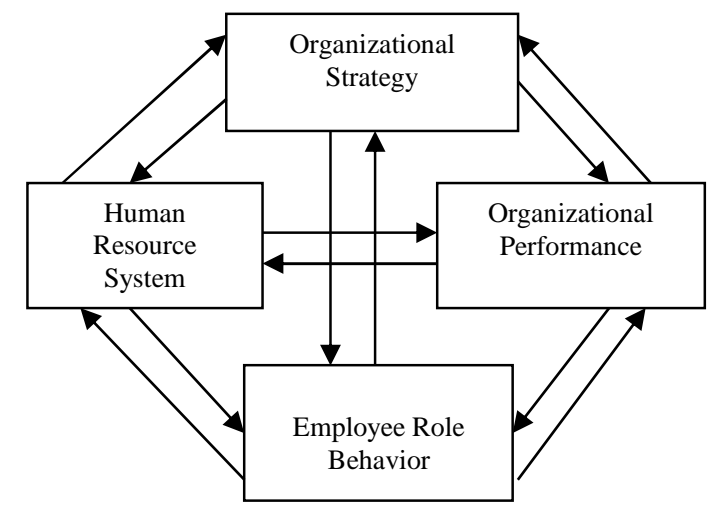

Fig. 1. Theoritical Model of Causal Relationship in Behavioral Perspective of Strategic Human Resource Management

Based on a literature review related causal relationships between variables in a behavioral perspective of strategic human resource management, we proposed theoretical model (Figure 1). Theoretical model describes causal relationship in behavioral perspective of strategic human resources management. In this case, behavioral perspective of strategic human resource management is analoged as a complex system which have elements interact in it dynamically, one and another.

\section{CONCLUSIONS AND SUGGESTIONS}

Based on a literature review, it is evident that between variables of behavioral perspective in strategic human resource management have an interdependence relationship. Theoretical framework in behavioral perspective of strategic human resource management is proposed, as a system which includes subsystems such as organizational strategy, human resource system, role behavior and organizational performance. Between one sub system and another, there are interdependence relationships. That theoretical framework is proposed to fill gaps in the field of behavioral perspective strategic human resource management, which has been analyzed in linier perspective.

Empirical studies are needed to prove scientific validity of behavioral perspective in strategic human resource management model which is proposed. The goal is to see how these elements interact in dynamics and interdependence causal relationships.

\section{ACKNOWLEDGMENTS}

I would like to give appreciation to my promotor, Prof Ferdinand D. Saragih, MA. and co-promotor, Dr. Andreo Wahyudi Atmoko, M.Si., for the advices, guidances and assistances provided to me throughout my doctoral journey.

\section{REFERENCES}

[1] Arthur, Jeffrey B., The Link between Business Strategy and Industrial Relations Systems in American Steel Minimills, Industrial and Labor Relations Review, Vol. 45, No. 3, April 1992, p488-506.

[2] Arthur, J.B., Effects of Human Resource Systems on Manufacturing Performance and Turnover, The Academy of Management Journal, Vol. 37, No. 3, June 1994, p670-687.

[3] Andrews, Rhys; Boyne, George A.; Walker, Richard M., Strategy Content and Organizational Performance: An Empirical Analysis, Public Administration Review, Vol. 66, No. 1, January-February 2006, p52-63.

[4] Baird, Lloyd and Meshoulam, Ilan, Managing Two Fits of Strategic Human Resource Management, The Academy of Management Review,Vol. 13, No. 1, January 1988, p116-128.

[5] Barney, Jay B., Looking Inside for Competitive Advantage, The Academy of Management Executive, Vol. 9, No. 4, November 1995, p49-61.

[6] Barney, Jay B. \& Clark, Delwyn N., Resource-Based Theory Creating and Sustaining Competitive Advantage, Oxford University Press, New York, 2007.

[7] Bateman, T.S., \& Organ, D.W., Job Satisfaction and The Good Soldier : The Relationship Between Affect and Employee Citizenship Academy of Management Journal, Vol. 26, No.4, 1983, p587-595.

[8] Beard, Donald W.; Dess, Gregory G. Corporate-Level Strategy, Business-Level Strategy, and Firm Performance, The Academy of Management Journal, Vol. 24, No. 4, December 1981, p663-688.

[9] Beatty, Richard W., Huselid, Mark A. and Schneier, Craig Eric, New HR Metrics : Scoring on the Business Scorecard, In Strategic Human Resource Management, eds R. Schuler and S. Jackson, Blackwell Publishers Ltd., Oxford, 1999, p343-384.

[10] Becker, Brian; Gerhart, Barry, The Impact of Human Resource Management on Organizational Performance : Progress and Prospects. The Academy of Management Journal,Vol. 39, No. 4, August 1996, p779-801. 
[11] Becker, Brian E;Huselid, Mark A;Pickus, Peter S;Spratt. Michael F., As A Source of Shareholder Value : Research and Recommendations, Human Resource Management (1986-1998), 36 (1), 1997, p39-47.

[12] Becker, Brian E.; Huselid, Mark A.; Ulrich Dave, The HR Scorecard : Linking People, Strategy and Performace. Harvard Business School Press, Boston, 2001.

[13] Bienstock, C. C., DeMoranville, C. W. \& Smith, R. K., Organizational Citizenship Behaviour and Service Quality, Journal of Services Marketing, Vol. 17, No. 4, 2003, p357-78.

[14] Boselie, Paul; Brewster, Chris; Paauwe, Jaap, In Search of Balance Managing The Dualities of HRM : An Overview of The Issues, Personnel Review Vol. 38 No. 5, 2009, p461-471.

[15] Chadwick, Clint, Examining Non-Linear Relationships between Human Resource Practices and Manufacturing Performance, Industrial and Labor Relations Review,Vol. 60, No. 4, July 2007, p499-521.

[16] Chang, Pao-Long; Chen, Wei-Ling, The Effect of Human Resource Management Practices on Firm Performance : Empirical Evidence from High-tech Firms in Taiwan, International Journal of Management, Vol.19, No.4, December 2002, p622-631.

[17] Combs, James;Liu, Yongmei;Hall, Angela;Ketchen, David, How Much Do High Performance Work Practices Matter : A Meta-Analysis of Their Effects on Organizational Performance, Personnel Psychology; Vol. 59, No.3, 2006, p501-528.

[18] Datta, Deepak K.; Guthrie, James P.;Wrigth, Patrick M., Human Resource Management and Labor Productivity: Does Industry Matter?, The Academy of Management Journal, Vol. 48, No. 1, February 2005 , p135-145.

[19] Delery, John E;Doty, D Harold, Modes of Theorizing in Strategic Human Resource Management : Tests of Universalistic, Contingency and Configurational Performance Predictions, Academy of Management Journal, Vol.39, No.4, August 1996, p802-835.

[20] Dess, Gregory G. and Davis, Peter S., Porter's (1980) Generic Strategies as Determinants of Strategic Group Membership and Organizational Performance, The Academy of Management Journal, Vol. 27, No. 3, September 1984, p467-488.

[21] Doty, D. Harold;Glick, William H.; Huber, George P., Fit, Equifinality, and Organizational Effectiveness: A Test of Two Configurational Theories. The Academy of Management Journal, Vol. 36, No. 6 (Dec., 1993), p1196-1250.

[22] Evans, Paul AL., The Strategic Outcomes of Human Resource Management" Human Resource Management (1986-1998), Vol.25, No.1, 1986, p149-167

[23] Frederickson, James W., Fredrickson Effects of Decision Motive and Organizational Performance Level on Strategic Decision Processes, The Academy of Management Journal, Vol. 28, No. 4, December 1985 , p821-843.

[24] Gibson, James I.; Ivancevich, John M.;Donnely, James H., Organisasi dan Manajemen ; Perilaku, Struktur dan Proses; Cetakan Kedelapan. Jakarta : Penerbit Erlangga, 1993.

[25] Ginsberg, Ari \& Venkantraman, N., Contingency Perspectives of Organizational Strategy : A Critical Review of The Empirical Research, The Academy of Management Review, Vol. 10, No. 3, July 1985, p421434.

[26] Harris, Christopher, Strategic Human Resource Management at The Crossroads : Relationships Among Human Resource Capital, Overlapping Tenure, Behaviors, and Performance, Dissertation. The University of Texas at Arlington, 2009.

[27] Huselid, Mark A;Becker, Brian E., The Impact of High Performance Work Systems, Implementation Effectiveness, and Alignment With Strategy on Shareholder Wealth, Academy of Management. Best Papers Proceedings, 1997, p144-148.

[28] Huselid, Mark A;Jackson, Susan E;Schuler, Randall S., Technical and Strategic Human Resource Management Effectiveness as Determinants of Firm, Academy of Management Journal, Vol. 40, No. 1, February 1997, p171-188.

[29] Huselid, Mark A;Becker, Brian E., The Impact of High Performance Work Systems, Implementation Effectiveness, and Alignment With
Strategy on Shareholder Wealth, Academy of Management. Best Papers Proceedings, 1997, p144-148.

[30] Ichniowski, Casey;Shaw, Kathryn;Prennushi, Giovanna, The Effects of Human Resource Management Practices on Productivity: A Study of Steel Finishing Lines, The American Economic Review, Vol. 87, No.3, June 1997, p291-313.

[31] Ichniowski, Casey;Shaw, Kathryn, The Effects of Human Resource Management Systems on Economic Performance : An International Comparison of U.S. and Japanese Plants, Management Science, Vol. 45, No. 5, May 1999, p704-721.

[32] Itami, Hiroyuki, Mobilizing Invisible Assets, Harvard University Press, Boston, 1987.

[33] Jackson, Susan E; Schuler, Randall S., Understanding Human Resource Management in The Context of Organizations and Their Environments, Annual Review of Psychology, Vol. 46, 1995, p237-264.

[34] Jennings, Daniel F;Lumpkin, James R., Insights Between Environmental Scanning Activities and Porter's Generic Strategies: An Empirical Analysis, Journal of Management, Vol. 18, No. 4, December 1992, p791-803.

[35] Johnson, Diane E.; Davis, Stan B.; Albright, Thomas L., Examining the Relationship between Employee Attitudes and a Firm's Financial Performance: A Theoretical Framework and Causal Investigation, Journal of Managerial Issues, Vol. 21, No. 3, 2009, p367-382.

[36] Kaplan, Robert S. and Norton, David P., The Balanced Scorecard : Translating Strategy Into Action, Boston :Harvard Business School Press, 1996

[37] Kaplan, Robert S; Norton, David P., The Strategy Map : Guide to Aligning Intangible Asset, Strategy \& Leadership, Vol.32, No.5, 2004 p10-17.

[38] Katou, Anastasia A., Investigating Reverse Causality Between Human Resource Management Policies and Organizational Performance in Small Firms, Management Research Review Vol. 35 No. 2, 2012, 134 156

[39] Katz, D; Kahn, R.L., The Social Psychology of Organizations, New York : Wiley, 1978.

[40] Kim, Linsu;Lim, Yooncheol, Environment, Generic Strategies, And Performance In A Rapidly Developing Country : A Taxonomic Approach, Academy of Management Journal, Vol.31, No.4, December 1988, p802-827.

[41] Lee, Jangwoo;Miller, Danny, People Matter: Commitment to Employees, Strategy and Performance in Korean Firms, Strategic Management Journal, Vol. 20, No. 6, June 1999, p579-593.

[42] Lengnick-Hall, Mark L. \& Lengnick-Hall, Cynthia A., Strategic Human Resources Management: A Review of the Literature and a Proposed Typology, The Academy of Management Review, Vol. 13, No. 3, July 1988, p454-470.

[43] Lengnick-Hall, Mark L. \& Lengnick-Hall, Cynthia A., Human Resource Management in The Knowledge Economy. New Challeges, New Roles, New Capabilities, Berret-Koehler Publishers, Inc., San Fransisco, 2003

[44] Lepak, David P., Strategic Human Resource Management : A Look to The Future, In Strategic Human Resource Management, R. Schuler and S. Jackson. Second Editions Blackwell Publishers Ltd., Oxford, 2007.

[45] Macduffie, John Paul, Human Resource Bundles and Manufacturing Performance : Organizational Logic and Flexible Production Systems in the World Auto Industry. Industrial and Labor Relations Review, Vol. 48, No. 2, January 1995, p197-221.

[46] March, James G. \& Sutton, Robert I., Organizational Performance as a Dependent Variable, Organization Science, Vol. 8, No. 6, NovemberDecember 1997, p698-706.

[47] Mayo, Andrew, Human Resources or Human Capital ? Managing People as Assets, Gower Publishing Limited, England, 2012.

[48] Messersmith, Jake G.; Patel, Pankaj C.; Lepak, David P.; GouldWilliams, Julian S., Unlocking the Black Box: Exploring the Link Between High-Performance Work Systems and Performance, Journal of Applied Psychology,Vol. 96, No. 6, 2011, p1105-1118. 
[49] Miller, Danny, Configurations of Strategy and Structure: Towards a Synthesis, Summary Strategic Management Journal (1986-1998), Vol. 7, No. 3, May-June 1986, p233-249.

[50] Miller, Danny, Relating Porter's Business Strategies To Environment And Structure., Academy of Management Journal, Vol. 31, No. 2, June 1988, p280-308.

[51] Nandakumar, M.K; Ghobadian,Abby; O’Regan, Nicholas, Generic Strategies and Performance - Evidence From Manufacturing Firms, International Journal of Productivity and Performance Management, Vol. 60 No. 3, 2011, p222-251.

[52] Nishii, Lisa H;Lepak, David P;Schneider, Benjamin, Employee Attributions of The "Why" of HR Practices : Their Effects on Employee Attitudes and Behaviors and Customer Satisfaction, Personnel Psychology, Vol. 61, No. 3, 2008, p503-545.

[53] Ogilvie, John R., The Role of Human Resource Management Practices in Predicting Organizational Commitment, Group \& Organization Studies (1986-1998), Vol. 11, No. 4, December 1986, p335-359.

[54] Osterman, Paul, How Common is Workplace Transformation and Who Adopts it?, Industrial and Labor Relations Review, Vol. 47, No. 2, January 1994, p173-188.

[55] Pati, Surya Prakash; Kumar Pankaj, Work Engagement: A Rethink, Indian Journal of Industrial Relations, Vol. 47, No. 2, October 2011, p264-276.

[56] Paul, A.K; Anantharaman,R.N., Search of the Missing Link in HRMPerformance Paradigm, Indian Journal of Industrial Relations, Vol. 37, No. 2, October 2001, p257-264.

[57] Payne, Stephanie C.; Webber, Sheila Simsarian, Effects of Service Provider Attitudes and Employment Status on Citizenship Behaviors and Customers' Attitudes and Loyalty Behavior, Journal of Applied Psychology, Vol. 91, No. 2, 2006, p365-378.

[58] Piening, Erk P.; Baluch, Alina M.; Salge, Torsten Oliver, The Relationship Between Employees' Perceptions of Human Resource Systems and Organizational Performance: Examining Mediating Mechanisms and Temporal Dynamics, Journal of Applied Psychology, Vol. 98, No. 6, 2013, p926-947.

[59] Podsakoff, P.M. \& MacKenzie, S.B., Impact of Organizational Citizenship behavior on Organizational Performance: A Review and Suggestions for Future Research, Human Performance, 10, 1997, p133155.

[60] Porter, Michael E., Competitive Strategy : Techniques for Analyzing Industries and Competitors, The Free Press, New York, 1980.

[61] Porter, Michael E., Competitive Advantage : Creating and Sustaining Superior Performance, New York : The Free Press, 1985.

[62] Porter, Michael E. (1996). What is Strategy?. Harvard Business Review, November-December 1996.

[63] Schuler, Randall S; MacMillan, Ian C., Gaining Competitive Advantage through Human Resource Management Practices, Human Resource Management (pre-1986), Vol. 23, No. 3, 1984, p241-254.

[64] Schuler, Randall S. and Jackson, Susan E., Linking Competitive Strategies with Human Resource Management Practices. The Academy of Management Executive (1987-1989),Vol. 1, No. 3, August 1987, p207-219.

[65] Schneider, Benjamin; Hanges, Paul J.; Smith, D. Brent; Salvaggio, Amy Nicole, Which Comes First: Employee Attitudes or Organizational Financial and Market Performance?, Journal of Applied Psychology, Vol. 88, No. 5, 2003, p836-851.

[66] Shirley, Robert C., Limiting the Scope of Strategy: A Decision Based Approach, The Academy of Management Review, Vol. 7, No. 2, April 1982, p262-268.

[67] Smith, C.A., Organ, D.W., \& Near, J.P., Organizational Citizenship Behavior: Its Nature and Antecedents, Journal of Applied Psychology, Vol.68, 1983, p655-663.

[68] Sun, Li-Yun; Aryee, Samuel; Law, Kenneth S., High-Performance Human Resource Practices, Citizenship Behavior, and Organizational Performance : A Relational Perspective, Academy of Management Journal, Vol. 50, No. 3, 2007, p558-577.

[69] Takeuchi, Riki, How Do We Get From There to Here ? Understanding The Black Box in Strategic HRM Research From Resource-Based and Social Exchange Perspectives, Dissertation,University of Maryland, 2003.

[70] Uen, Jin-feng; Chien, Michael S.; Yen, Yu-Fang, The Mediating Effects of Psychological Contracts on the Relationship between Human Resource Systems and Role Behaviors: A Multilevel Analysis, Journal of Business and Psychology, Vol. 24, No. 2, June 2009, p215-223.

[71] Williams, Larry J., Affective and Nonaffective Components of Job Satisfaction and Organizational Commitment as Determinants of Organizational Citizenship and In-Role Behaviors, Dissertation, Indiana University, 1988.

[72] Wright, Patrick M; Snell, Scott A., Toward a Unifying Framework for Exploring Fit and Flexibility in Strategic Human Resource Management, Academy of Management. Review; Oct 1998; 23, 4, 1998, p756-772.

[73] Wright, Patrick M;Gardner, Timothy M;Moynihan, Lisa M., The Impact of HR Practices on The Performance of Business Units, Human Resource Management Journal, Vol. 13, No, 3, 2003, p21-36.

[74] Wright, Patrick M; Haggerty, John J., Missing Variables in Theories of Strategic Human Resource Management : Time, Cause, and Individuals, Management Revue, Vol. 16, No. 2, 2005, p164-173.

[75] Wright, Patrick M;Gardner, Timothy M;Moynihan, Lisa M;Allen, Mathew R., The Relationship Between HR Practices and Firm Performance : Examining Causal Order, Personnel Psychology, Vol. 58, No. 2, 2005, p409-446.

[76] Youndt, Mark A.; Snell, Scott A; Dean, James W., Jr.; Lepak, David P., Human Resource Management, Manufacturing Strategy, and Firm Performance, The Academy of Management Journal,Vol. 39, No. 4, August 1996, p836-866.

[77] Zerbe, Wilfred J;Dobni, Dawn;Harel, Gedaliahu H., Promoting Employee Service Behaviour : The Role of Perceptions of Human Resource Management Practices and Service Culture, Revue Canadienne des Sciences de l'Administration, Vol. 15, No. 2, June 1998, p165-179. 